\title{
Putting higher education in its place in (East Asian) political economy Bob Jessop
}

This is a pre-copy edited version of a paper of the same title In Comparative Education, forthcoming in 2016, http://dx.doi.org/10.1080/03050068.2015.1128659

\section{Abstract}

This article relates changes in higher education and research in East Asian societies to recent trends in political economy and, in particular, the reorientation of developmental states in the region. The developmental state is oriented to catch-up competitiveness and, as the horizon of development shifts, so do its appropriate institutional forms and strategies. Catch-up competitiveness is guided by economic imaginaries, often linked to geoeconomic, geopolitical, and broader societal imaginaries, whose hegemony depends on particular discursive and disciplinary practices. The shift in the roles of $\mathrm{HE}$ and research is related to the reorientation of developmental states from export-oriented, investment-led growth to knowledgeintensive, investment-led growth, supplemented in some cases by efforts to create international financial hubs to exploit a global trend towards financialisation. These themes are explored through comparison of selected East Asian economies/societies. The article ends with some general conclusions about the state's continuing role in higher education and its internationalisation in the region.

\section{Keywords:}

catch-up competitiveness; developmental state; higher education; knowledge-based economy; internationalisation; neo-liberalism; neo-mercantilism; research;

\section{Acknowledgements}

I am grateful to Terri Kim for the invitation to submit this paper to the special issue and to participants in conferences on the Developmental State at Hong Kong Baptist University, Hong Kong, 16-17 December 2013, and on Academic Capitalism at Jena University, Germany, 16-18 March 2015, for feedback for some of the ideas presented 
here. Terri Kim and an anonymous reviewer provided critical but encouraging feedback on the first draft. Ngai-Ling Sum has been a co-author on related research and Eva Hartmann, Norman Fairclough, Poul Fritz Kjaer, Susan L Robertson, and Andrew Sayer also gave useful feedback on versions of the argument.

\section{Note on Contributor}

Bob Jessop is Distinguished Professor of Sociology and Co-Director of the Cultural Political Economy Research Centre, Lancaster University. He studied Sociology at Exeter University (1967) and obtained his PhD from Cambridge University (1972). He is best known for his contributions to state theory, social theory, critical political economy, the study of welfare state restructuring, and, most recently, cultural political economy. His most recent book is The State: Past, Present, Future (2015). 


\section{Putting higher education in its place in (East Asian) political economy Bob Jessop}

Sociology, Lancaster University, Lancaster LA1 4YN, UK

This contribution to the special issue of Comparative Education provides a cultural political economy perspective on the internationalisation of higher education (HE) in East Asia and interprets this as part of broader changes in the region's political economy. There is a vast literature on internationalisation of $\mathrm{HE}$ as a convergent trend in world society and the intellectual value-added of this article, if any, is to put this and related changes in their place in terms of new economic imaginaries, the dynamics of variegated capitalism on a global scale, various local, national and regional responses to the 1997-1998 'Asian crisis', and the specificities of developmental states (DSs) in this region. ${ }^{1}$ For, while there are certainly signs of convergence, the mechanisms producing this vary across economies, states, societies and regions and merit contextualisation. This would show the limits to convergence in a world market (including for education and research) that is highly variegated thanks to diverse complementarities and contradictions among economies at different scales within and beyond East Asia (see, for example, the contributions in Menkhoff et al., 2011).

The 'Asian crisis' that erupted in 1997 prompted a search for alternative economic and political strategies and related efforts to recalibrate and reorient DSs. While these attempts were mainly national, they were shaped by two major economic imaginaries and associated paradigms that were circulating in advanced economies too: the knowledge-based economy (KBE) and neoliberal financialisation. In this context, imaginary denotes meaning systems that cognitively simplify an inordinately complex world as a condition of "going on" within it, frame individual subjects' "lived experience" of that world, and/or inform collective action oriented thereto (Sum and Jessop 2013, 165). The KBE imaginary extrapolates past and present social trends into a performative vision of the future to shape an economic dynamic that seeks to valorise "knowledge" as the key driver of economic growth, wealth generation, and job creation in the private, public, and "third" sectors (Olssen and Peters 2005; Godin 2006; Jessop 2008; Hornidge 2011). It has major implications for the reorganisation and reorientation of the wider society at multiple sites and scales and in many social fields. 
It can also take neo-statist, neo-corporatist, neo-liberal, neo-communitarian and hybrid forms (Jessop 2002). Financialisation is another general economic and social trend (for an overview, see van der Zwan 2014) that is strongly promoted by the International Monetary Fund (IMF) and World Bank among other international agencies. In its neoliberal form, however, it leads to finance-dominated accumulation, which privileges financial capital over other kinds of capital, with pervasive repercussions on virtually all social relations as well as creating special kinds of crisis (see Jessop 2013).

These imaginaries and associated policy paradigms have distinctive implications for the roles of HE in economic and social development. The OECD and World Bank (and macro-regional affiliates, such as the Asian Development Bank), and, more recently, the European Union have been promoting the KBE strongly from the mid-1990s (a key document is OECD 1996; on the World Bank as an education policy governor, see Mundy and Verger 2015). However, whereas the OECD has been fairly consistent in its advocacy, the World Bank's position has changed considerably. It now argues that the returns to investment in $\mathrm{HE}$ are greater than in basic education and is more aware of the limitations of market-driven reforms (see Obamba 2013). The KBE concept was anticipated in the notions of "information economy" and "information society" in Japan (Umesao 1963; Masuda 1981), where it influenced policy significantly from the 1980s; it was also adopted relatively early in some first- and second-generation East Asian newly industrialised countries (hereafter EANICS), which also promoted national systems of innovation, the learning economy, and the KBE (for a comprehensive overview, see Hornidge 2011).

The main contemporary global rival to the KBE (broadly interpreted) as an economic imaginary and strategy is finance-led accumulation, which prioritises the deregulation and liberalisation of finance, the role of financial capital and capital markets in allocating capital to different activities, the financialisation of all economic sectors including, through market proxies, the public sector, and the internationalisation of financial flows (van der Zwan 2014). Financialisation arrived in East Asia as much through external pressure from trading partners and international organisations and through a massive increase in global liquidity, leading to greater financial integration of the world market (UNCTAD 2015), as it did through deliberate imitation or emulation of advanced, often neoliberal, economies and through explicit domestic goal-setting. 
Nationally, financialisation tends to be a secondary strategy in the EANICS compared to the KBE strategy and is linked to the growing importance of capital markets, especially venture capital and similar markets, in corporate finance compared to the earlier primacy of state credit relations. Promoting financialisation is an important part of government strategies in the region and is reflected in international 'financial hub' strategies, especially at metropolitan or city-state level. This is seen in South Korea and Singapore as part of their new catch-up competitiveness strategies as well as in the enhanced priority given to finance in Hong Kong's strategy to become 'Asia's World City' and in its new significance in the PRC, especially in Shanghai's resurgence as a global financial centre, the promotion of Shenzhen, and the rise of Beijing.

\section{The developmental state and the knowledge-based economy}

A developmental state (hereafter DS) is a state that plans, orchestrates or steers economic, political and societal strategies that are oriented to catching up with a more advanced (not necessarily the most advanced) reference economy or associated economic growth dynamic (Jessop 2016) This definition is not limited to EANICs or other national states but covers such strategies over longer time spans, at different scales, and in different kinds of polity (for a recent survey, see Caldentev 2008; also Reinert 2004, Green 2007; Beeson 2009; Pereira 2008). Moreover, while these strategies may target specific places, spaces, scales, and competitors, they are inevitably mediated via the world market - especially as this becomes more integrated through neoliberal strategies of market completion. The DS is a sub-type of competition state, which is a state that aims to create conditions for competitiveness within its borders and/or gain competitive advantages for enterprises based therein by promoting the economic and extra-economic actions currently deemed vital for success in competition with economic actors, sectors, and spaces in other states (Cerny 1990; Jessop 2002, 2016).

Successful catch-up competitiveness strategies are based on the following principles:

1) National wealth cannot be created or based on raw material production in the absence of a manufacturing/increasing returns sector. 
2) An inefficient manufacturing/increasing returns sector provides a much higher standard of living than no manufacturing sector (Reinert 2004).

Three further points are worth noting. First, the idea of 'competitiveness' is discursively constructed and rests on specific economic imaginaries, often articulated to geoeconomic, geopolitical and social imaginaries oriented to state- and nation-building or other major societal goals. This opens space for discursive struggles over the nature and bases of competitiveness. Different economic imaginaries imply different forms of political action with different effects on the competitive positioning of firms, sectors, cities, regions, and nations as well as on the domestic and international balance of forces. Second, as the leading edge of economic competition alters, so do patterns of competitive advantage and, hence, the demands of catch-up competitiveness. Third, crucially, education and research are now regarded as a critical 'increasing returns' sector with major benefits to the economy and civil society. Education is now seen as a branch of the economy rather than an extra-economic sphere with wide social functions. This is a global trend with specific resonance and impact in East Asia.

The Asian crisis prompted a re-evaluation of DS strategies which were initially based on labour-intensive production ${ }^{2}$ and, in a second, sometimes overlapping stage, on neomercantilist, investment-led growth oriented to export-driven catch-up competitiveness. This illustrates the role of crises as both threat and opportunity - here triggering or accelerating innovation-led, KBE strategies (on factor-, investment-, and innovationdriven competitiveness, see Porter 1990). This is reflected in broad discursive, policy, and institutional changes in government and governance in and across the region.

Discursively, new terms proliferated, such as national innovation systems, the KBE, K-economy, learning society, networked learning society, HE clusters, knowledge hubs, transnational education hubs, creative economy, smart cities, biopolis, triple helix, knowledge triangles, entrepreneurial universities, and entrepreneurial academics. These complementary technical, economic, educational and social imaginaries serve as aspirational self-descriptions of an economy or society (identifying what often exists only in embryo or potentia) and, in favourable circumstances, may guide a critical mass of expectations, state policies, organisational and institutional strategies and innovation, and so on to align and coordinate them with 
these views. The reorientation and reorganisation of $\mathrm{HE}$ is only one aspect of these broader sets of putative changes and should also be considered in this wider context.

Examples of policy reorientations are:

- Taiwan's commitment under the Democratic Progressive Party to become a 'Green Silicon Island' based on the KBE, sustainable development, and social justice as well as its promotion of an 'e-Taiwan' project to build e-business, egovernment, and an e-society (Chen and Lee 2004).

- South Korea's strategy to become a KBE, endorsed by the OECD and World Bank (Chu 2009) and its associated Brain Korea 21 and Brain Korea 21 Plus projects to boost research-intensive universities, develop a national innovation system, and build stronger and denser links between HEls and industry (Suh and Chen 2007).

- Singapore's strategy to become an "Intelligent Island", initiated in 1992 and currently in its sixth iteration, set out in 2006, under the rubric of "Intelligent Nation 2015", intended to exploit its self-described competitive advantage as a highly educated city-state and to promote innovation in creative industries (NCB 1992; Choo 1997; Hornidge 2010; IDA 2015a, 2015b, 2015c).

- Albeit more rhetorically, Hong Kong's strategy in the late 1990s (advocated by consultants and scholars linked to Massachusetts Institute of Technology) to re-industrialize the city-state based on high-tech and creative industries (on this, Masayama and Vandenbrink 2003; Lee and Cheng 2011; Sum 2010).

These discursive and strategic policy shifts have been reflected in turn in institutional transformations, with new ministries (or new names, marking a strategic reorientation), new planning instruments, the expansion and simultaneous stratification of the education sector at different levels, new research bodies and incentives, and so on.

The information (later, knowledge) economy arose as a theoretical paradigm in the 1960s. It drew on ideas about the creatively destructive nature of innovation, the virtues of entrepreneurial competition, and long waves in economic development associated with different leading edge and supporting technologies (Schumpeter 1934). This paradigm was translated into a broader policy paradigm in the 1980s 
based on observation of DS strategies in East Asia and became quite explicit in the 1990s, thanks to the OECD, World Bank, and European Union, among other actors. Policy-makers used it to guide economic and social strategies to become more competitive by using information and communication technologies and moving into knowledge- and design-intensive sectors to renew older branches and develop new ones in goods and services. More recently, the KBE has been integrated in even more simplified form into several consultancy packages marketed amid great hype as reliable tools to boost competitiveness from rural areas and inner cities to macroregions like the EU (besides Michael Porter's Monitor consultancy, Richard Florida's work on creative economies was influential in East Asia; for overviews and critiques, see Peck 2010; Sum 2010). Indeed, the KBE is a master narrative that shapes economic strategies, state projects, and societal visions from cities and regions via national and supranational states to international agencies and global regimes.

In significant respects, of course, every economy is a knowledge economy in so far as tacit, embedded, and codified knowledge are key aspects of production, circulation, and consumption. So we might ask what, if anything, is new about the modern KBE apart from the prominence of terms such as knowledge economy, knowledge-driven or knowledge-based economy (and equivalents in other languages) in contemporary economic imaginaries, economic and political strategies, and the self-descriptions and narratives of economic, political, and other social entities. In ideal-typical terms, the primary aspect of today's KBE is the valorisation and application of knowledge as the key factor in boosting the efficiency, competitiveness, profitability and/or effectiveness of the private, public and third sectors of the economy, improving governance, and enhancing the quality of life. This poses issues around the commodification of knowledge as intellectual property and its circulation as an intellectual commons. This tension is seen in OECD discourses on the role of universities in the KBE, especially concerning whether this is to provide a public good or to provide private benefit for students and other stakeholders (Hunter 2013; and below). ${ }^{3}$ And it poses particular problems for DS strategies where access to knowledge protected by various kinds of property rights or de facto monopolies is crucial to development until their economies begin to make major innovations worth protecting in the same way. 
Attempts to valorise knowledge involve (1) the radical expansion, differentiation, and recombination of diverse fields of knowledge, invention, innovation, and creativity involved in material and immaterial production; (2) efforts to create and valorise designand knowledge-intensive capital and manage the tensions between the intellectual commons and intellectual property; (3) measures to facilitate technological intelligence gathering, create independent technological capacities and promote innovative capacities, technical competence, and technology transfer; (4) policies to make labour markets more flexible, reorient social policy towards flexicurity, reskill and upgrade the workforce (including through a tough global war for talents), and promote entrepreneurial skills; and (5) an increasingly deliberate and reflexive application of knowledge to the production of knowledge to transform the technical and social forces of production.

The OECD, World Bank (and its regional affiliates), and the European Union have been major advocates of the KBE. The OECD led the way in articulating the concept and constructing data bases to compare and rank progress towards the KBE nirvana. The World Bank advocated "Knowledge for Development" policies as the best route to economic progress in "developing economies" (Robertson 2008). And, in its 2000 Lisbon Agenda, the EU committed itself, albeit unsuccessfully, to becoming the most competitive KBE in the world by 2010 . Other international agencies have jumped on the KBE bandwagon. Examples include the World Trade Organization (WTO), International Monetary Fund (IMF), the World Intellectual Property Organization (WIPO), the United Nations Conference on Trade and Development (UNCTAD). Regional economic blocs and intergovernmental bodies are also active. Examples include the Arab League, Asia Pacific Economic Cooperation (notably, its Economic Committee), ASEAN, NAFTA, various parts of the United Nations (UNCTAD, UNECE, UNESCO, UNPD, CEPAL, etc.), Mercosur (the Latin American trade bloc), and the Viségrad Four in Central Europe. Similar economic (albeit not always social) policies are being rolled out elsewhere by national states with quite different roles in the global division of labour (e.g., Colombia, Germany, New Zealand, South Korea, the United Arab Emirates, and the USA) as well as by diverse provinces, metropolitan regions, and small cities. Many other international organisations as well as regional blocs in the semi-periphery and periphery have also adopted KBE discourse and strategies. 


\section{Education as one element in the knowledge-based economy}

In response to the crisis in post-war growth regimes in advanced capitalist economies, education was criticised for its mismatch with a changing economy, creating slower growth and high unemployment. Emphasis later turned to its vital role in building human capital and the knowledge base to support economic competition in a global KBE (Peters 2001). Similar criticisms occurred in the EANICS from the 1990s onwards and led to a similar emphasis on recalibrating the economic significance of education (on Korea, see Suh and Chen 2007). This overturns Bell's forecast (1973) that postindustrialism would see profit-oriented industrial enterprises lose their previously dominant role in industrial society to commons-oriented universities. Yet these now tend to act like competitive, revenue-maximising enterprises that also aim to serve various local, urban, regional, national, or even supranational KBEs. Indeed, for Etzkowitz, a leading researcher on the "triple helix" interface between universities, business and the state, also writing during the transition period:

Virtually every country that has a university, whether it was founded for reasons of education or prestige, is now attempting to organize knowledgebased economic development. ... As the university becomes more dependent upon industry and government, so have industry and government become more dependent upon the university. In the course of the 'second academic revolution' a new social contract is being drawn up between the university and the wider society, in which public funding for the university is made contingent upon a more direct contribution to the economy (Etzkowitz 1994, 149, 151; compare Etzkowitz 2008; Leydesdorff 2010).

Reflecting these new economic imaginaries, promoting national and regional systems of innovation alongside vocational training and lifelong learning to boost transferable and specific skills became a central component of economic and social policy. Following initial calls for labour market flexibility and welfare austerity, the OECD later advocated measures to promote structural and/or systemic competitiveness based on extra-economic as well as economic practices and institutions. Developing a KBE became an explicit objective and was often linked to neo-Schumpeterian arguments about the shifting frontiers of technological innovation. In the 2000s, building capacity 
in science/technology/engineering/mathematics (STEM subjects) was stressed along with applied as well as basic research to create profitable products. A strong countertrend to these priorities stressed the role of creative and cultural industries. Pressure also grew to lower the fiscal 'burden' of vocational training, further education and HE, reflected in measures to make HEls compete for students and funding, cut or share costs, and become more entrepreneurial in raising external funds (Hunter 2013).

Three trends are noteworthy here. First, HE is increasingly construed as a directly economic factor to be governed in conjunction with other such factors to boost economic competitiveness rather than viewed in terms of its functional differentiation and specialisation within a stable social order. It is judged in terms of its economic efficiency and contributions to national systems of innovation, learning economy, KBE and "enterprise culture". Moreover, following the neoliberal agenda, higher educational services are being liberalised, de-regulated, privatised, and exposed to (inter-)national competition; funding sources are diversified; students are becoming sought-after mobile customers of these services; and knowledge and creativity are being commodified and intellectual property rights extended in scope and duration. Employers and practitioners are getting more involved in curriculum development; managers are drawn into educational governance and agenda-setting; mobility between the academy and non-academic worlds is fostered; and colleges and universities deliver lifelong learning (Teichler 1998). Relatedly, responsibility for finding gainful employment is shifted to individual workers - whether as enterprising individuals investing in their human capital or as equal citizens entitled to support from the state and social partners to improve their skills (see Brown, Lauder and Ashton 2011). East Asian DSs took this turn earlier, treating education as vital for economic performance at all stages from kindergarten through to $\mathrm{HE}$.

Second, education is increasingly construed in post-national terms (especially in HE and scientific research) and is being reorganised at various scales, including in diverse transversal, cross-national and multi-scalar ways (Marginson and Rhoades 2002). Reflecting the trend to internationalization, there is now a growing international industry of accreditation, quality assurance, standardisation, and benchmarking (Hartmann 2008). A parallel process is the multiplication of rankings to compare, order, 
and discipline schools, universities, and research institutions and their contribution to competitiveness (Hazelkorn 2015).

And, third, even where, against recent global trends, HE remains firmly embedded in the public sector, it is judged in terms of its impact on economic development (at regional, national, and supranational levels) and competitiveness (Godin 2006; Olssen and Peters 2005). The growth of closer and more continuous contacts with business, the professions, government and local communities is clearest in STEM subjects. There is more emphasis on patenting, technology transfer, research parks, commercial spin-offs, science and technology parks, incubators, consultancy services. But the same trend is seen in the humanities and social sciences regarding their impact on competitiveness and their contribution to the creative, cultural and copyright industries, government agendas, and capacities for social control.

These changes open space for monitoring mechanisms that can be adapted to changing global, regional, national and local conditions to rank, benchmark, and discipline units of assessment through the gaze of a paper panopticon. In addition to generic indexes of global economic competitiveness, many of which include quality of education and research (Sum 2010), and the World Bank Institute's Knowledge Index and Knowledge Economy Index, there are specific rankings for universities (notably, the Shanghai Jiao Tong University Academic Ranking of World Universities [ARWU], the Times Higher Education Supplement World University Rankings, and the QS Top Universities). Although criticised on scientific and policy grounds (e.g., Lall 2001; Marginson and van der Wende 2007; Hazelkorn 2015), they have disciplinary power in ranking units of assessment (countries, cities, schools, universities, departments, faculty members, etc.), publicising their strengths and weaknesses, recording their performance over time, and defining their current rank order. Annual revisions institutionalise a continuous gaze with performative effects far beyond their robustness and face validity. They drive an accelerating treadmill of competitiveness that creates pressures to follow best practice and adopt the latest strategic recipes based on the most recent, or still fashionable, economic imaginaries. The traditional Humboldtian model of university governance based on a community of scholars and students is being challenged by demands for greater accountability to a multi-tiered state system and to business interests ranging from small- and medium-sized firms to national and 
international champions. This holds even for world-class universities, which gain some autonomy from national pressures only to face them on a global scale (on the problems that this has created in Japan, see Tsuruta 2013). These pressures extend across an ever-expanding range of economic and extra-economic factors and has produced a veritable 'education industry' mind-set that affects the self-identity and actions of those charged with the governance of higher education and research.

\section{Implications for higher education and research}

Schumpeter identified five areas of innovation: (1) the introduction of a new good or a new quality of a good; (2) the introduction of a new method of production or a new way of commercially handling a commodity; (3) the opening of new markets for one's own products; (4) securing a new source of supply of raw materials or half-finished goods; and (5) the reorganisation of an industry, for example, the creation of a new cartel or monopoly position, or the breaking up of existing cartels or monopolies (Schumpeter 1934: 129-35). Successful competition in these areas allows, in the short-term, monopoly profits. In a well-functioning market, however, these higher profit-levels will eventually be competed away as other firms adopt these innovations or seek to counter them with their own innovations (whether competitive or anti-competitive). In addition to the immediate relevance of Schumpeter's schema to the KBE considered as a whole, including the competing away of temporary competitive advantages as others imitate or improve on these innovations, there are also analogous forms of innovation and treadmill effects in HE. Thus entrepreneurial HE institutions may:

(1) Provide new preparatory courses; extend degree programmes; introduce new or enhanced programmes in $\mathrm{HE}$, professional training, and research that reflect new disciplines, new economic and political priorities, or major shifts in the cutting edge and supporting technologies of new waves of economic and social development.

(2) Introduce new methods of teaching and research, copy "best practices", exploit new or enhanced information and communication technology (ICT) infrastructures and "infostructures", seek to cut costs and boost efficiency by standardising or commoditising education, find new ways to deliver their 'products', such as offering 
on-line rather than correspondence courses for part-time, continuing and distance education, or providing English-medium teaching.

(3) Open new markets - for example, in validating degrees or internationalisation of education. This occurs by diversifying the source of students (Wildavsky 2010), opening international branches (this can be done alone, through twinning, partnerships, consortia, and franchising or other commercial ties), introducing $1+2$ or $2+2$ courses, or developing new kinds of regional education hubs in Asia, with progressively more demanding inputs and outputs (Knight and Morshidi 2011).

(4a) Secure a new source of supply of raw materials or half-finished goods - analogies could include widening the recruitment base for students of all ages, the global competition for talent (sourcing post-graduate and post-doctoral researchers from abroad, introducing "flying faculty" or recruiting world-class or international faculty); or, conversely, resort to adjunct, flexible, or casual intellectual labour (e.g., Hawkins and Xu 2012 on "brain circulation" in the Asia Pacific region).

(4b) Find new funding sources besides the public purse or student fees - including business and third sector research contracts, third mission activities, patents and royalties, private-public partnerships, wealthy donors, and alumni programmes; for states, open the education sector to private enterprise and foreign direct investment.

(5) Reorganise the 'education industry' and scientific research by investing heavily in creating 'world-class' universities that can challenge existing educational and research hierarchies in the interests of boosting the competitiveness of national KBEs.

The overall result of the first four kinds of innovation is an "academic capitalism" that turns faculty members into enterprising bearers of intellectual capital on behalf of entrepreneurial universities (Slaughter and Leslie 1997; Slaughter and Rhoades 2004). The fifth kind of innovation indicates that the entrepreneurial university à la Schumpeter should also be related to the strategic reorientation of DSs as the horizons of catch-up competitiveness shift towards innovation-led development and the scope and size of the "market" for education and research are extended. East Asia is prominent here, with growing financial and political commitment to education, research 
and development. This affects governance in internal management, accounting, audit, learning modes, incentives, career tracks, and so on as well as regarding external partnerships, knowledge transfer, political guidance, and government controls (for a good overview of shifts in East Asian HE governance, see Mok 2007).

Two apparently contrary but actually complementary strategies are being adopted. On the one hand, states are pushing the contribution of education to vital economic interests as redefined in the light of new hegemonic economic imaginaries; and, on the other hand, states are conceding greater autonomy to educational institutions in how they serve these interests. Whereas the first strategy reaffirms the character of education as a "public good", the second regards it as a business, subjects it to market disciplines, and treats it as a "private good" (Marginson 1999, 122; Hunter 2013). Together, these strategies reinforce the primacy of economic calculation in the HE sector and tend to create an increasingly stratified hierarchy of institutions stretching from world-class or leading research universities, located at the cutting-edge of the KBE and transformational technologies, which attract global talents and engage in international research cooperation, to institutions that specialise in cost-effective mass credentialisation and opportunities for life-long learning at a more local or regional scale. In all cases, however, there is growing emphasis on close links to the users and stakeholders so that economic needs are met as far as possible.

\section{Some East Asian vignettes}

There is little turnover in the top 100 universities (still US-dominated) but, depending on the index, Asia has 4 (ARWU), 11 (THES), or 19 (QS) in the top 100 in 2015; and 17 (ARWU), 19 (THES), and 39 (QS) in the top 200 (see the respective websites). These data show improvements over earlier years and there is even more upward mobility in the top 400 thanks to concerted efforts in Asian economies to improve their position (Postiglione and Arimoto 2015). Indeed, the Shanghai ARWU index was "developed as a strategic tool to help set an appropriate standard and target for China" (Hazelkorn 2015, xviii). More generally, this striving occurs through DS support and sponsorship, encouraged in many cases by the World Bank and regional affiliates, to make HE and research a key driver in competitiveness within a much broader vision of the knowledge economy (see, for example, Asian Development Bank 2014). 
Japan, China, and South Korea have large and strong bases in profit-producing (industrial and post-industrial) sectors and all three invest heavily in world-class or internationally competitive education and research oriented to new technological frontiers, including knowledge-intensive business services as well as other designand knowledge-intensive services. Taiwan shares this orientation. As smaller citystates with larger cross-border hinterlands, Hong Kong and Singapore have consolidated their positions as service economies and are also, respectively, the third and fourth most important global financial centres in 2015 after London and New York. Tokyo and Seoul come fifth and sixth but are part of much larger economies (Qatar Financial Centre Authority 2015). All four East Asian global financial centres aim to strengthen their position through active state support for further financialisation (Economic Review Committee 2002; Lai 2012; Park 2011). I now present some vignettes on how East Asian DSs have been recalibrating and reorienting their catchup competitiveness and/or consolidation strategies since the Asian crisis.

\section{South Korea}

In response to the 1997-8 "Asian" crisis, the Republic of Korea made several neoliberal policy adjustments in its approach to economic development without undertaking a more radical neoliberal regime shift. It also reoriented its catch-up strategy towards the knowledge economy (cf. Taiwan's contemporaneous commitment to becoming a technologically advanced nation). Following the 2007-8 "global financial crisis", this reorientation of the DS state towards the KBE was reaffirmed when, under President Lee Myung-bak, the government created a Ministry of the Knowledge Economy (MKE) in 2008. Its mission was to promote the knowledge economy, which would add value to traditional goods and services through greater levels of research and innovation intelligence, adding value and making them more competitive globally. It declared that, 'different from other economic models which rely primarily on natural resources or manpower, knowledge will be the primary engine of productivity and growth for the Korean economy' (italics in original). Above all, the Ministry aimed 'to assemble traditional industrial know-how, cutting edge R\&D, and strong pro-business policies' (Ministry of the Knowledge Economy 2008). Its remit also included developing new growth engines by supporting ICTs and high-end manufacturing, promoting foreign 
trade, attracting FDI, and developing environmentally-friendly projects by promoting a green economy (Erawatch 2012).

This strategy was revived by another new ministry in 2013: the Ministry of Science, ICT and Future Planning (MSIP), which was tasked with leading the development, coordination and implementation of 'creative economy' policies. This initiative reflected the vision of incoming President Park Geun-hye. She wanted to create a 'Second Miracle on the Han River' by promoting a "creative economy". This would stimulate growth and employment through "the convergence of science and technology with industry, the fusion of culture and industry, and the blossoming of creativity" (Park 2013). This reflects a belief that "the global economic paradigm is shifting from a 'Knowledge Economy' to a 'Creative Economy', which creates added value through innovative technologies and creative ideas" (MOTIE 2015). Reflecting a neoSchumpeterian view of economic development, President Park's programme praises entrepreneurs as "carriers of innovation" in products, services, processes, markets, and business models. Core manufacturing industries are still crucial here but the chaebol no longer have a privileged position. Thus the programme has six strategic pillars: an ecosystem that encourages start-up companies; a strengthened economic role for start-ups and small- and medium-enterprises and measures to enhance their ability to enter global markets; generate new industries as growth engines; foster world-class creative talent; strengthen science, technology, and ICT to promote innovation; and spur a creative economic culture within Korean society (Connell 2013).

As a secondary strategy, favoured by the IMF and World Bank, demanded by domestic firms outside "the iron triangle of bank-chaebol-government" (Fukugawa 1998), and endorsed by central government, South Korea has spurred financialisation to back this initiative (e.g., facilitating venture capital and promoting KOSDAQ in imitation of NASDAQ as automated exchanges for high-tech, start-up companies) and developing plans to transform South Korea into an international financial hub linked, in part, to its hoped-for role as a North East Asian industrial hub.

\section{Singapore}

Singapore also illustrates the survival and adaptation of the DS strategy in new 
circumstances. The state retains a prominent economic role thanks to its control of the land market, key role in the allocation of capital, and influence over housing, employment, infrastructure and "infostructure". Consistent with the state's continual recalibration of its catch-up competitiveness strategy when it gained independence as a small, resource-poor island in 1965, Singapore's government is now pursuing an Intelligent Nation strategy, building on its previous mass education, reskilling, smart city and intelligent island strategies and its 2004 commitment to develop a "national innovation system" (on this concept, see Nelson 1993). This reflects the KBE strategy of investing in world class education and ICT to enhance global competitiveness According to a Minister of Education, Teo Chee Hean, Singapore has a vision:

... to become the Boston of the East. Boston is not just MIT or Harvard. The greater Boston area boasts of over 200 universities, colleges, research institutes and thousands of companies. It is a focal point of creative energy; a hive of intellectual, research, commercial and social activity. We want to create an oasis of talent in Singapore: a knowledge hub, an "ideas-exchange", a confluence of people and idea streams, an incubator for inspiration (Teo, 2000, cited in Mok, 2008, 532).

The strategy begins in kindergarten and is linked to the slogan: "Thinking Schools, Learning Nation". Internationalisation is crucial here in schools, colleges, further and higher education and the regional education hub initiative has been branded as "The Global Schoolhouse". Alongside recruiting students and faculty from the wider region, world-class universities have been attracted to Singapore to set up joint programmes, research partnerships, and branch campuses. As in Korea, education and research are being reoriented to fifth and sixth Kondratieff long wave technologies, such as biotech, biomedical, creative industries, health care, and green technologies. Moreover, consistent with this strategy, the state pays retraining fees (Gopinathan 2007). Matching the "Boston of the East" vision, the state is also promoting the "OneNorth Project" modelled after Silicon Valley to create a high-tech research community.

A related strategic aim is to attract $R \& D$ firms and multinational companies specialising in the knowledge economy and service industries (Knight and Morshidi 2011). And, again reflecting the new mantra of the creative economy, Singapore is building on its 
1990s national cultural policies to promote Singapore as a "Global City of the Arts" and to develop the cultural, creative and copyright industries (Hornidge 2011). Changes in HE governance that align with World Bank polices have also been implemented: partial privatisation; attracting inward investment; corporatisation; internal competition; private-public partnerships; the user pays principle; and accountability to stakeholders (Mok 2008). Like Taiwan, Singapore has improved its ranking substantially on the World Bank's Knowledge Economy Index from 1995 to the present (Asian Development Bank 2014). Finally, as in South Korea, the state aims to strengthen the economy's position as global financial hub (Economic Review Committee, 2002).

\section{Hong Kong}

Hong Kong's economic strategies reflect conflicts between profit-producing and financial capital. After its 1997 'return to the motherland', there were two rival strategies. The first, recommended by scholars and consultants associated with MIT, was to redevelop its industrial base through re-industrialisation in high tech sectors, creative industries, and closer tighter integration of finance and industry. The second strategy, promoted by scholars and consultants linked to Harvard Business School, was to strengthen Hong Kong's role as a financial and business services centre and maintain the close ties between the finance and real estate sectors (Sum 2010). Tung Che-Hwa, the then Chief Executive, aligned himself with the former strategy in his 2004 Policy Address, aiming to turn Hong Kong into 'Asia's World City', including making it a regional hub in higher education (Knight and Morshidi 2011). However, financial and property interests exploited the 2007-8 financial crisis to reorient government strategy. Thus, while maintaining plans to boost educational, medical, testing and certification, and cultural and creative services, a new Chief Executive (and former financial secretary), Donald Tsang, affirmed a finance-led strategy to consolidate Hong Kong's position as a low tax, low public spending, global financial centre and key supplier of business services to an ever more powerful China (Lee and Cheng 2011; Knight and Morshidi 2011). This fitted China's ambitions to use Hong Kong in its strategy to develop as a financial power and internationalise the Renminbi. 


\section{Malaysia}

The same strategic orientation is seen in second-tier emerging markets such as Malaysia, which Malaysia's "2020 vision" and master planning to move from a commodity-exporting and low-wage, labour-intensive economy to a "K-economy" (Prime Minister's Department 2001). Knowledge for development has been crucial here, initially through investment in mass education, training, and reskilling and more recently through continuing commitment to upgrading the skilled workfare and promoting HE, knowledge and innovation. In 2007 it established a Ministry of Higher Education to make and implement long-term plans to strengthen the ties between education and economic development and, in line with World Bank recommendations, promote liberalisation and privatisation (including greater encouragement to private education institutions), improve efficiency, reduce the burden on the public purse, and contribute to Malaysia's global competitiveness by increasing critical mass in science and technology (World Bank and Economic Planning Unit 2007). A related initiative is to develop a regional education hub (Azman, Sirat and Karim 2010). Two initiatives here, which are part of bigger commercial and residential projects (and may, therefore, also be read as real estate developments) are an 'Educity', situated near Singapore, and a Kuala Lumpur Education City (Knight and Morshidi 2011). Indeed, here as elsewhere, KBE discourse can be used to legitimate actions and investments undertaken for other motives.

\section{Conclusions}

This article presents no fresh data on the internationalisation of HE in East Asia. Its aim was to put this trend in its place in (East Asian) political economy. Specifically it explored the strategic reorientation and structural transformation in East Asian DSs in response to the 1997-8 "Asian" crisis and the "global financial crisis" that erupted in 2007-8 as guided by hegemonic economic imaginaries that were circulating in diverse theoretical and policy spaces. This approach offers a more specific account than invoking general trends such as globalisation, internationalisation, or competitiveness focusing instead on (dis)continuities in catch-up strategies in East Asia compared with other sites in a variegated world economy. Thus, while affirming the familiar narrative about the internationalisation of $\mathrm{HE}$, which results from shared strategies as well as 
structural drift, the article looks beyond convergent empirical trends to particular pathdependent legacies of East Asian political economy that define specific path-shaping opportunities in changing regional and global contexts. It also turned from internationalisation as such towards the broader role of education as an increasingly critical factor in KBE strategies (loosely defined) and interpreted the latter in terms of the emergence, selection, and consolidation of a new economic imaginary to make sense of, and guide responses to crisis. In short, the KBE should be understood as a theoretical and policy paradigm with performative effects rather than a simple description of objective tendencies unfolding "behind the backs" of producers, managers, and consumers of knowledge and policy-makers. It also has specific strategic and structural selectivities.

As the World Bank notes, the KBE has different implications at different stages of economic development. Further, the scope for knowledge economies also depends on the articulation among local, regional, national and quasi-continental economies. For example, while the US leads in world-class universities, its broader education system (especially in STEM subjects) has serious structural weaknesses; indeed, relative to the size and wealth of its economy, it actually underperforms on university rankings by 4-10 percent (Hazelkorn 2015, xiv). The resulting gap is being filled by "well-trained international graduate students and skilled immigrants from countries such as India, China, Korea and Singapore (the last two of which rank at the top in mathematics and science achievement)" (Chellaraj, Maskus and Mattoo 2004, 2, cited Hazelkorn 2015, xiv). This indicates the role of complementarities in a variegated world market (also in the global war for talents) as well as the scope for new forms of imperialism and colonialism based on uneven development. It also supports the selfdescribed speculative hypothesis that "knowledge capitalism will exhibit different patterns of production, ownership and innovation according to five basic regional models of capitalism" (Olssen and Peters 2005, 339). ${ }^{4}$ Anna-Katharina Hornidge likewise observed in her review of national information infrastructure projects in the 1980s that Japan hoped to overcome the hollowing out of its manufacturing industry, the European Union to address the pressures of global competition and stagflation, and the USA to resolve an infrastructural crisis (Hornidge 2011, 32). Indeed, as indicated above, internationalisation is mediated through the specific place and 
functions of HEls as local, regional, national, and transnational champions in accumulation strategies, state projects, and hegemonic visions.

For East Asia, while there may be a "Confucian" tradition (Marginson 2011), the recent importance attached to education, especially HE and research, has much to do with the sequencing of developmental state catch-up competitiveness strategies as each strategy showed signs of exhaustion, was successfully copied by emerging markets elsewhere in the region or wider world market, or was exposed as vulnerable by acute national, regional or global crises. This explains the timing of the KBE shift after the "Asian" crisis, which happened to coincide with its more general advocacy by the OECD and World Bank; and this turn also benefitted from the latecomer advantages of a developmental state that had a strong record of, and capacities for, investing in education, training, and reskilling. Likewise, as perceived horizons of competitive advantage now include financialisation and as GATS, the Trans-Pacific Partnership, and TiSA (Trade in Services Agreement) require the opening of financial as well as educational markets, we also observe plans to establish international financial hubs as well as transnational education hubs that are based on revamped developmental state capacities oriented not only to regulatory changes but also to creating the infrastructure and infostructure needed to realise financial hub strategies with all their agglomeration, networked and cluster effects. A final remark in regard to both strategies is required, namely, that there is "many a slip "twixt cup and lip". Many more strategies are proposed than can possibly succeed and a wider survey of East Asian political economy would need to consider competing interpretations of the KBE and financialisation strategies as well as other rival strategies and, in addition, assess their feasibility at the national scale and in terms of the opportunities in a variegated capitalism that sets limits to what is compossible across different regional economies. A salutary lesson in this regard comes from the difficulties of imitating the "Silicon Valley" model around the world. There is no simple recipe for success and more strategies fail than succeed.

\section{Notes}

${ }^{1}$ On cultural political economy, see Sum and Jessop (2013); on variegated capitalism, 
Jessop (2015); and on developmental states, Jessop (2005. 2016).

2 Dubai illustrates the less common resource-intensive DS strategy directed towards long-term economic security and competitiveness in other areas (Joshi 2012).

${ }^{3}$ The OECD's reports on its Tertiary Education for the Knowledge-Based Economy project justify the need for HE reform and growth in terms of its public benefits. Yet, when discussing who should fund for this expansion, $\mathrm{HE}$ is constructed primarily as a private benefit (Hunter 2013, 719).

${ }^{4}$ Olssen and Peters mention Anglo-American capitalism, European social market capitalism, French state capitalism, the Japanese model and an emergent model based on China's market socialism $(2005,339)$. The present article also indicates variegation in East Asia itself.

\section{References}

Asian Development Bank 2014. Innovative Asia. Advancing the Knowledge-Based Economy. Manila: ADB.

Azman, N., M. Sirat and M. A. Karim 2010. "Building future scenarios for Malaysian universities." Journal of Asian Public Policy 3 (1): 86-99.

Bell, D. 1973. The Coming of Post-Industrial Society. New York: Basic Books.

Beeson, M. 2009. "Developmental states in East Asia: A comparison of the Japanese and Chinese experiences." Asian Perspective 33 (2): 5-39.

Brown, P., H. Lauder and D. Ashton 2011. The Global Auction. The Broken Promises of Education. Oxford: Oxford University Press.

Caldentev, E.P. 2008. "The concept and evolution of the developmental state." International Journal of Political Economy 37 (3): 27-53.

Cerny, P. G. 1990. The Changing Architecture of Politics. London: SAGE.

Chellaraj, G., K. E. Maskus, and A. Matoo 2004. The contribution of skilled immigration and international graduate students to U.S. innovation. Washington, DC: World Bank. https://openknowledge.worldbank.org/handle/10986/8957.

Chen, T-Y. and J. S. Lee (Eds) 2004. The New Knowledge-Economy of Taiwan. Cheltenham, UK: Edward Elgar. 
Choo, C. W. 1997. "IT2000: Singapore's vision of an intelligent island." In Intelligent Environments: Spatial Aspects of the Information Revolution, edited by P. Droege, 49-66. Amsterdam: North-Holland Elsevier.

Chu, Y.-W. 2009. "Eclipse or reconfigured? South Korea's developmental state and challenges of the global knowledge economy." Economy and Society 38 (2): 278303.

Connell, S. 2013. Building a Creative Economy in South Korea. Washington DC: Korea Economic Institute of America, Academic Papers, 10 December.

Economic Review Committee [Sub-Committee on Services Industries: Financial Services Working Group]. 2002. Positioning Singapore as a Pre-Eminent Financial Centre in Asia, Singapore.

Erawatch 2012. Organisation: Ministry of Knowledge Economy. Brussels: European Commission.

Etzkowitz, H. 1994. "Academic-industry relations." In Evolutionary Economics and Chaos Theory, edited by L. Leydesdorff and P. van den Desselaar, 139-151. London: Pinter.

Etzkowitz, H. 2008. The Triple Helix: University-Industry-Government Innovation in Action. London: Routledge.

Fukugawa, Y. 1998. The Korean Economy at Great Transformation Period. Seoul: Nanam Publishing.

Godin, B. 2006. "The knowledge-based economy: conceptual framework or buzzword?" Journal of Technology Transfer 31 (1): 17-30.

Gopinathan, S. 2007. "Globalization, the Singapore developmental state and education policy: A thesis revisited". Globalization, Societies, and Education 5 (1): 53-70.

Green, A. 2007. "Globalisation and the changing nature of the state in East Asia." Globalisation, Societies and Education 5 (1): 23-38.

Hartmann, E. (2008). "The EU as an emerging normative power in the global knowledge-based economy?" In Education and the Knowledge-Based Economy in Europe, edited by B. Jessop, N. Fairclough, and R. Wodak, 63-86. Rotterdam: Sense.

Hawkins, J. N. and J. Xu 2012. "Mobility, migration and the road to the innovative university: implications for the Asia-Pacific region." Journal of Asian Public Policy 5 (3): 255-265. 
Hazelkorn, E. 2015. Rankings and the Reshaping of Higher Education: The Battle for World-Class Universities, $2^{\text {nd }}$ edition. Basingstoke: Palgrave-Macmillan.

Hornidge, A.-K. 2010. "An uncertain future: Singapore's search for a new focal point of collective identity and its drive towards 'knowledge society". Asian Journal of Social Science 38: 785-818.

Hornidge, A.-K. 2011. “'Knowledge society' as academic concept and stage of development - a conceptual and historical review". In Beyond the Knowledge Trap: Developing Asia's Knowledge-Based Economies, edited by T. Menkhoff, HD. Evers, Y. W. Chay, and E. F. Pang, 87-128. Singapore: World Scientific. http://ssrn.com/abstract=1861024, accessed 12 November 2015.

Hunter, C. P. 2013. "Shifting themes in OECD country reviews of higher education." Higher Education 66: 707-23.

IDA 2015a. Empowering Learners and Engaging Minds, through Infocomm. Singapore: Infocomm Development Authority of Singapore.

IDA 2015b. Leveraging Infocomm to ensure Singapore's prospects in the financial markets. Singapore: Infocomm Development Authority of Singapore.

IDA 2015c. Realising the iN2015 Vision. Singapore: an intelligent nation, a global city, powered by infocomm. Singapore: Infocomm Development Authority of Singapore. Jessop, B. 2002. The Future of the Capitalist State. Cambridge: Polity.

Jessop, B. 2005. "Beyond developmental states: A regulationist and state-theoretical analysis". In Asian States: Beyond the Developmental Perspective, edited by R. Boyd and T.-W. Ngo, 19-42. London: Routledge.

Jessop, B. 2008. "A cultural political economy of competitiveness and its implications for higher education." In Education and the Knowledge-Based Economy in Europe, edited by B. Jessop, N. Fairclough, and R. Wodak, 11-39. Rotterdam: Sense.

Jessop, B. 2013. "Revisiting the regulation approach: critical reflections on the contradictions, dilemmas, fixes, and crisis dynamics of growth regimes." Capital \& Class 37 (1): 5-24.

Jessop, B. 2015. "Comparative capitalisms and/or variegated capitalism." In New Directions in Critical Comparative Capitalisms Research, edited by I. Bruff, M. Ebenau and C. May, 65-82. Basingstoke: Palgrave-Macmillan.

Jessop, B. 2016. "The developmental state in an era of finance-dominated accumulation." In The Asian Developmental State: Reexaminations and New Departures, edited by Y.-W. Chu, 27-55. New York: Palgrave-Macmillan. 
Joshi, D. 2012. "Varieties of developmental states: Three non-western paths to the Millennium Development Goals." Journal of Developing Societies 28 (3): 355-78. Knight, J. and S. Morshidi 2011. "The complexities and challenges of regional education hubs: Focus on Malaysia." Higher Education 62: 593-606.

Lai, J. 2012. Financial Crisis and Institutional Change in East Asia, Basingstoke: Palgrave-Macmillan.

Lall, S. 2001. "Competitive indices and developing countries: an economic evaluation of the Global Competitiveness Report." World Development 29 (9): 1501-25.

Lee, K. M. and C. Y. Cheng 2011. "Financialization, economic crises and social protection: the case of Hong Kong." Journal of Asian Public Policy 4 (1): 18-41.

Leydesdorff, L. 2010. "The knowledge-based economy and the triple helix model." Annual Review of Information Science and Technology 44: 367-417.

Marginson, S. 1999. "After globalisation: emerging politics of education." Journal of Education Policy 14 (1), 19-31.

Marginson, S. 2011. "Higher education in East Asia and Singapore: Rise of the Confucian model." Higher Education 61 (5): 587-611.

Marginson, S. and G. Rhoades 2002. "Beyond national states, markets and systems of higher education: A glonacal agency heuristic". Higher Education 43 281-309.

Marginson, S. and M. van der Wende 2007. "To rank or be ranked: The impact of global rankings in higher education." Journal of Studies in International Education 11 (3-4) 306-29.

Masayama, S. and D. Vandenbrink (Eds) 2003. Towards a Knowledge-Based Economy: East Asia's Changing Industrial Governance, Singapore: Institute for East Asian Studies.

Masuda, Y. 1981. The Information Society as Post-Industrial Society. Washington, DC: World Future Society.

Menkhoff, T., H-D. Evers, Y. W. Chay and E. F. Pang (Eds) 2011. Beyond the Knowledge Trap: Developing Asia's Knowledge-Based Economies. Singapore: World Scientific.

Ministry of the Knowledge Economy. 2008. "Overview". Online (but no longer available, cited in Erawatch 2012) http://www.mke.gov.kr/language/eng/index.jsp. Mok, K. H. 2007. "Globalisation, new education governance and state capacity in East Asia." Globalisation, Societies and Education 5 (1): 1-21. 
Mok, K. H. 2008. "Singapore's global education hub ambitions. University governance change and transnational higher education." International Journal of Educational Management 22 (6): 527-46.

MOTIE 2015. "Korean industrial initiatives for the creative economy." Seoul: Ministry of Trade, Industry and Energy.

Mundy, K. and A. Verger 2015. "The World Bank as an education policy governor." In Actors and Agency in Global Social Governance, edited by A. Kaasch and K. Martens, 64-80. Oxford: Oxford University Press.

National Computer Board 1992. A Vision of an Intelligent Island: IT2000 Report. Singapore: National Computer Board.

Nelson, R. R. (Ed.) 1993. National Innovation Systems: A Comparative Analysis. New York: Oxford University Press.

Obamba, M. O. 2013. "Uncommon knowledge: World Bank policy and the unmaking of the knowledge economy in Africa". Higher Education Policy 26: 83-108.

OECD 1996. The Knowledge-Based Economy. Paris: OECD.

Olssen, M. and M. A. Peters 2005. "Neoliberalism, higher education and the knowledge economy: from the free market to knowledge capitalism." Journal of Education Policy 20 (3): 313-345.

Park, Y. S. 2011. "Developing an international financial center to modernize the Korean service sector", Washington DC: Korea Economic Institute of America Academic Papers, \#47.

Park, G. H. 2013. "Opening a new era of hope (18th Presidential Inaugural Address)." 25 February, Office of the President (Republic of Korea).

Peck, J. 2010. Constructions of Neoliberal Reason. New York: Oxford University Press.

Pereira, A. 2008. "Whither the developmental state? Explaining Singapore's continued developmentalism." Third World Quarterly 29 (6): 1189-1203.

Peters, M A. 2001. "National education policy constructions of the "knowledge economy': Towards a critique." Journal of Education Enquiry 2 (1): 1-22.

Porter, M. E. 1990. The Competitive Advantage of Nations. London: Macmillan.

Postiglione, G. A. and A. Arimoto 2015. "Building research universities in East Asia." Higher Education 70: 151-3.

Prime Minister's Department 2001. Developing Malaysia into a Knowledge-Based Economy. 8th Malaysia Plan. pp. 119-43. 
Qatar Financial Centre Authority 2015. Global Financial Centres Index 18. Qatar: Qatar Financial Centre Authority.

Reinert, E. S. 2004. How rich nations got rich. Essays in the history of economic policy. Working Paper Nr. 2004/01, University of Oslo: SUM.

Robertson, S. L. 2008."'Producing' knowledge economies: The World Bank, the KAM, education and development" In Re-Reading Education Policies, edited by M. Simons, M. Olssen, and M. Peters, 235-257. Rotterdam: Sense.

Schumpeter, J. A. 1934. Theory of Economic Development: An Inquiry into Profits, Capital, Credit, Interest and the Business Cycle, Boston, MA: Harvard University Press.

Slaughter, S. and L. L. Leslie 1997. Academic Capitalism. Politics, Policies, and the Entrepreneurial University. Baltimore: Johns Hopkins University Press.

Slaughter, S. and G. Rhoades 2004. Academic Capitalism and the New Economy: Markets, State, and Higher Education. Baltimore: Johns Hopkins University Press. Suh, J. and D. C. H. Chen (Eds.) 2007. Korea as a Knowledge Economy. Evolutionary Processes and Lessons Learned. Washington, DC: Korea Development Institute and World Bank Institute.

Sum, N-L. 2010. "A cultural political economy of transnational knowledge brands: Porterian 'competitiveness' discourse and its recontextualization in Hong Kong/Pearl River Delta." Journal of Language and Politics 9 (4): 546-73.

Sum, N-L. \& B. Jessop 2013. Towards a Cultural Political Economy: Putting Culture in its Place in Political Economy, Cheltenham: Edward Elgar.

Teichler, U. 1998. "The role of the European Union in the internationalization of higher education." In The Globalization of Higher Education, edited by P. Scott, 88-99. Buckingham: Open University Press.

Teo, C. H. 2000. "Education towards the 21st century - Singapore's universities of tomorrow". [Alumni International Singapore (AIS) Lecture, 7 January]. Singapore: Ministry of Education.

Tsuruta, Y. 2013. "The knowledge society and the internationalization of Japanese higher education." Asia Pacific Journal of Education 33 (2): 140-155.

Umeseo, T. 1963. "Information industry theory: dawn of the coming era of the ectodermal industry". Hoso Asahi, January: 4-17 [in Japanese].

UNCTAD 2015. "Financialization and its macroeconomic discontents. Making the international financial architecture work for development". In: Secretariat of the 
United Nations Commission on Trade and Development (Ed.), Trade and Development Report, 2015, 37-54. New York: UNCTAD.

van der Zwan, N. 2014. "State of the art: Making sense of financialization." SocioEconomic Review 12 (1): 99-129.

World Bank and Economic Planning Unit (2007). Malaysia and the Knowledge Economy: Building a World Class Higher Education System. Kuala Lumpur, Malaysia: World Bank and EPU, Report 40397.

Wildavsky, B. 2010 The Great Brain Race: How Global Universities are Reshaping the World. Princeton, NJ: Princeton University Press. 